\title{
Effects of the Truckee California, Earthquake of September 12, 1966
}

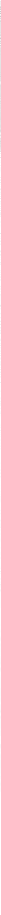





\section{Effects of the Truckee California, Earthquake of September 12, 1966}

By Reuben Kachadoorian, R. F. Yerkes, and A. O. Waananen

GEOLOGICAL SURVEY CIRCULAR 537

A contribution to west-coast earthquake investigations

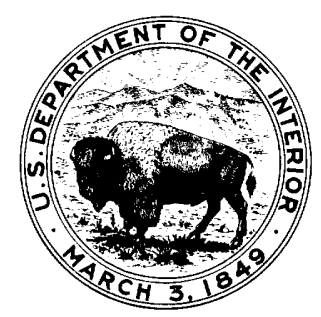


United States Department of the Interior STEWART L. UDALL, Secretary

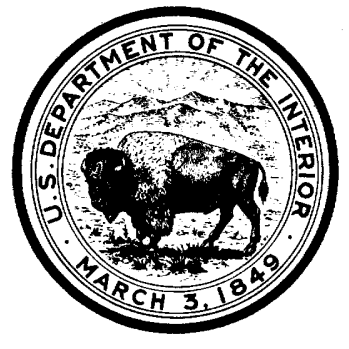

\section{Geological Survey}

William T. Pecora, Director

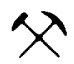




\section{CONTENTS}

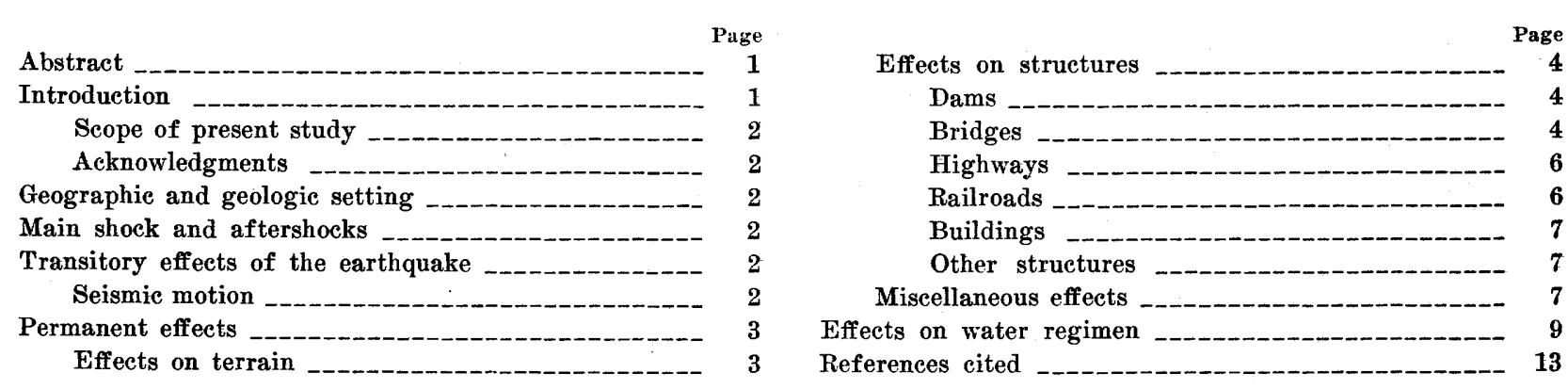

\section{ILLUSTRATIONS}

Plate 1. Map showing location of Truckee earthquake effects, epicenters of earthquakes of magnitude 4.0 and larger, and faults

FIgURE 1. Index map showing location of Truckee earthquake epicenter and area over which it was felt

2. Map showing location of zone of ground breakage

3. Photograph showing small slump in unconsolidated deposits on west bank of Prosser Reservoir

4. Plan-view sketch of Prosser Dam showing extent and relative location of cracks in crest of dam

5. Sketch of cross section of Prosser Dam showing location and inferred extent of cracks in dam

6. Photograph showing southwestward view along crest toward right abutment of Prosser Dam

7. Photograph showing east abutment of eastbound lane bridge of Interstate Highway 80 spanning railroad tracks and Truckee River at Union Mills

8. Sketch of abutments of eastbound lane bridge of Interstate Highway 80 at Union Mills and type of damage to east and west abutments

9. Sketch of west abutment of westbound lane bridge of Interstate Highway 80 at Union Mills

10. Photograph showing southward view of repaired crack near Hinton on Interstate Highway 80._-_._ 9

11. Sketch section of Interstate Highway 80 near Hinton showing location of break at cut-fill contact 10

12. Photograph showing one of two toppled chimney at watermaster's house, Boca Dam

13. Photograph showing eastward view of small powerhouse at Farad on Truckee River 3 miles east of Boca Reservoir showing near-circular hole punctured in brick wall by large falling boulder

14. Map showing selected gaging stations whose records showed effects of Truckee earthquake

15. Chart showing fluctuations recorded at gaging stations in response to the Truckee earthquake

\section{TABLE}




\title{
Effects of the Truckee, California, Earthquake of September 12, 1966
}

\author{
By Reuben Kachadoorian, R. F. Yerkes, and A. O. Waananen
}

\begin{abstract}
The Truckee, Calif., earthquake of September 12, 1966, had a magnitude of 5.4 on the Richter scale, as reported by the U.S. Coast and Geodetic Survey. It was felt over an area extending from San Francisco eastward to Salt Lake City and from Bakersfield northward beyond Chico, Calif. Ground breakage due to seismic shaking oceurred in unconsolidated alluvium along a zone about 10 miles long that trends about N. $30^{\circ}$ E. and extends from a point west of Prosser Reservoir, 4 miles northeast of Truckee, to Hoke Valley. The concentration of ground breakage along this zone suggests that it may be related to a subsurface northeastward-trending fault rather than to buried extensions of the northwestward-trending faults that dominate the regional geologic structure.

Other effects of the earthquake include the following: (1) Damage to Prosser and Boca Dams, (2) minor damage to several bridges on Interstate Highway 80, (3) several earthquake-generated slumps or landslides on Interstate Highway 80 between Boca Dam and the California-Nevada boundary, (4) damage to the caretaker's house at Boca Dam and a lumber shed at Loyalton, (5) damage by falling rocks to the Farad powerhouse, to the wooden flume which supplies water to the powerhouse, and to the Southern Pacific Lines in Truckee Canyon, (6) minor damage to water wells and water distribution systems, particularly at Truckee, and (7) rejuvenation of springs throughout the Truckee-Russel Valley area.
\end{abstract}

\section{INTRODUCTION}

The Truckee earthquake of September 12, 1966 , occurred at 9:41 a.m. P.d.t. (1641 G.m.t.) and was estimated to have had a Richter magnitude of 5.4 by the U.S. Coast and Geodetic Survey, of 6.256.5 by the California Institute of Technology at Pasadena, and of 6.1 by the University of California at Berkeley.

The earthquake was felt over an area which extended from San Francisco on the west to Salt Lake City on the east and from Bakersfield on the south to Chico on the north (fig. 1). Russel Valley, about 8 miles north-northeast of Truckee, was the only area to show any permanent effects of the earthquake.

About 21 seismic shocks greater than magnitude 4 (fig. 2) are reported in the area for the period 1934-61 by the California Department of Water Resources (1964). None of the 21 epicenters is known to be associated with faulting at the ground surface, although some in the northwestern part of the area can be associated spatially with northwestward-trending faults that are buried in the Truckee area ( south of lat $39^{\circ} 30^{\prime} \mathrm{N}$.).

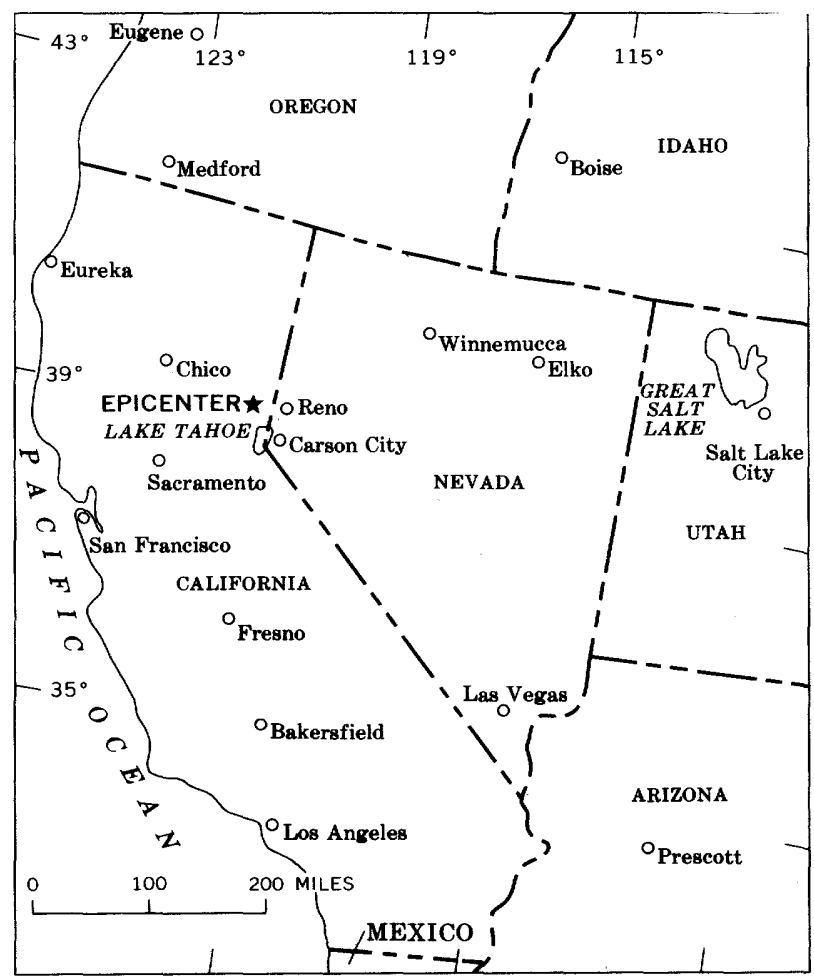

FIGURE 1.-Location of the epicenter of the Truckee earthquake and area over which it was felt. Open circles indicate cities where the earthquake was felt. 


\section{Scope of present study}

The purpose of the investigation described her was to locate and document the significant effects of the earthquake and, where possible, to relate them to the geologic environment. The investigation extended over a 3-day period beginning late on September 13, the day following the main shock.

\section{Acknowledgments}

We received help from numerous people, particularly Mrs. A. L. Scott, Chico, Calif.; Mrs. R. M. Gwinn, Sacramento, Calif.; Mr. Frank Fox and Mr. H. C. Johnson, California Division of Highways; Dr. L. J. Payen, Sacramento, Calif.; Mr. Reuben Alcala, Southern Pacific Lines; Mr. B. H. Crater, U.S. Bureau of Reclamation; and $\mathrm{Mr}$. Francis Longo, Truckee Utility District.

\section{GEOGRAPHIC AND GEOLOGIC SETTING}

The Truckee-Russel Valley area is located within the "Truckee Basin" (Birkeland, 1963)--an intermontane basin that, with the Lake Tahoe basin to the south, is flanked by the 9,000 -foot-high Sierra Nevada on the west and the 10,000-ft-high Carson Range on the east. The area is underlain by Tertiary lavas and pyroclasties north of lat. $39^{\circ} 30^{\prime}$ $\mathrm{N}$. and by Pliocene and Pleistocene basalt and latite flows to the south. West of Donner Lake the faulted east escarpment of the Sierra Nevada is underlain by Mesozoic granitic rocks that intrude Mesozoic metasedimentary and metavoleanic rocks (Burnett and Jennings, 1962). Except for its occurrence in canyon bottoms, bedrock throughout the lower lying parts of the area is buried by deposits of glacial, landslide, colluvial, lake, and alluvial material.

\section{MAIN SHOCK AND AFTERSHOCKS}

The initial instrumental epicenter of the earthquake was lat $39^{\circ} 30^{\prime} \mathrm{N}$., long $120^{\circ} 00^{\prime} \mathrm{W}$., about 15 miles northwest of Truckee, Calif. The U.S. Coast and Geodetic Survey (1966) reported the epicenter in Boca Reservoir at lat $39.4^{\circ} \mathrm{N}$, long $120.1^{\circ} \mathrm{W}$. and the focal depth at 8 kilometers. The U.S. Coast and Geodetic Survey reported the Richter magnitude of the earthquake as 5.4; the University of California at Berkeley, 6.1; and the
California Institute of Technology, 6.25-6.5.

Surface effects suggest that the epicenter was located 10 miles west-southwest of Verdi and in the vicinity of Russel Valley. The valley is 9 miles north-northeast of Truckee at lat $39^{\circ} 26^{\prime \prime} \mathrm{N}$., long $120^{\circ} 08^{\prime} \mathrm{W}$.

There were more than a thousand aftershocks within a week following the earthquake; many aftershocks seem to have been generated in the immediate vicinity of Prosser Reservoir. According to preliminary estimates, the focal depths of the aftershocks were less than $5 \mathrm{~km}$ and maybe around $2 \mathrm{~km}$ (Roger Greenfelder, oral commun., 1966). The preliminary instrumental locations of some of the aftershocks appear to correspond olosely with the surficial effects of the main shock.

The known effects of the earthquake were entire. ly due to seismic shaking. The permanent and transitory effects are keyed by locality to the map on plate 1. In addition to localized ground breakage, the earthquake affected dams, bridges, highways, buildings, railroad, water facilities, pipelines, and a flume.

\section{TRANSITORY EFFECTS OF THE EARTHQUAKE}

\section{Seismic motion}

The character and duration of the seismic motion throughout the area apparently depended upon the distance from the epicenter and the local geologic environment.

Mrs. R. M. Gwinn of Sacramento reported that shaking lasted 20-30 seconds and was in a southeast-northwest direction. At Chico, Mrs. A. L. Scott was having a telephone conversation with a friend 15 miles $(24 \mathrm{~km})$ east of Chico and felt the earthquake 4-5 sec after the person to whom she was speaking felt the motion. Mrs. Scott reported two distinct shocks a few seconds apart in which the motion was rolling-east-west in direction of vibration-and lasted for about 15-20 sec.

Oral reports of witnesses indicate that the direction of motion was northeast-southwest at Truckee and Tahoe City, north-south at Verdi, and eastwest at Sierraville and Loyalton. Sierraville and Loyalton are built on alluvium; residents of these areas reported a rolling motion that lasted for about 30 sec. At Truckee, Mr. Richard Keylor was on bedrock and stated that the motion was sharp 
and lasted for about 10 sec. However, in the alluviated area of the Truckee Airport, about 2 miles southwest of Truckee, Mr. Lester Michael reported that the seismic motion was of a rolling nature and lasted for about 30 sec. At Tahoe City, located on the northwest shore of Lake Tahoe approximately 20 miles southwest of Russel Valley, the motion was rolling and was felt for about 15 sec; Tahoe City is built on a thin veneer of sediments overly. ing bedrock.

Observers on unconsolidated sediment or at a distance from the epicenter felt a rolling motion, whereas those on bedrock or close to the epicenter felt a jarring motion.

\section{PERMANENT EFFECTS \\ Effects on terrain}

Broken ground, slumping and fissuring of natural and artificial fill, and rock falls were found along a zone trending north-northeast about 5 miles wide and 10 miles long centered in the Russel Valley area (fig. 2).

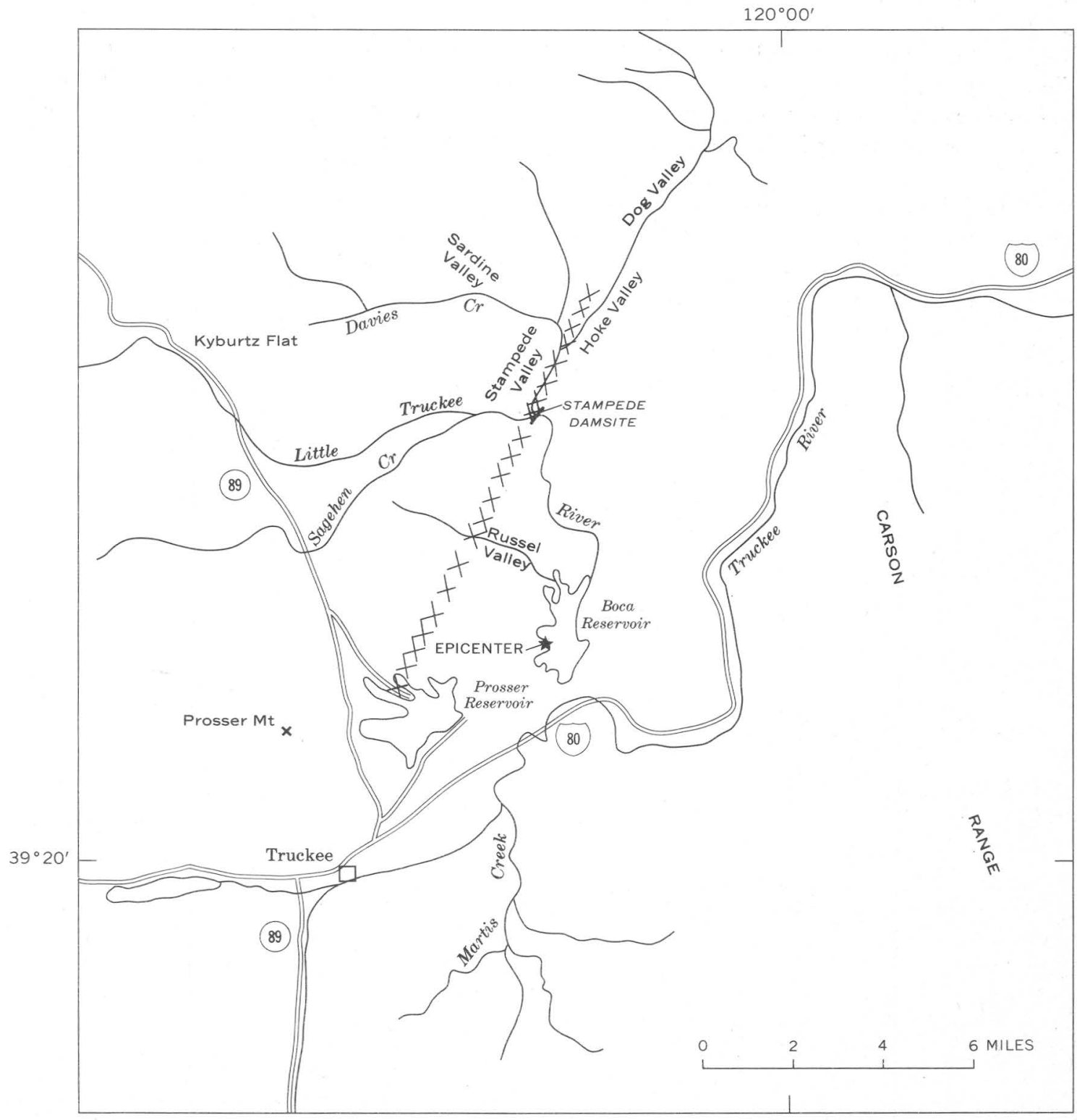

FIGURE 2.-Location of zone of ground breakage. 
Minor but extensive ground breakage occurred in a zone about 10 miles long that trends about $\mathrm{N}$. $30^{\circ} \mathrm{E}$; t the zone ranges in width from about $75 \mathrm{ft}$ near Prosser Reservoir and Hoke Valley to about 1 mile in Russel Valley. Ground breakage was confined to low elongated areas of unconsolidated natural fill, commonly subparallel to the zone. The breakage is expressed locally as cracks, slightly sinnous small ridges, wedges, and mounds of freshly disturbed soil and turf; the linear features are commonly oriented subparallel to the zone and are as much as $20 \mathrm{ft}$ long. Pebbles were locally overturned. All these effects are attributed entirely to shaking but are in no case associated with lateral spreading of the ground toward an unconfined face. They may be, however, associated with the effects of topography on the passage of gravitational waves. (See Coulter and Migliaccio, 1966, p. 20.)

Alinement of the zone of ground breakage with the trend of a fault exposed at the Stampede damsite (fig. 2) suggests an association with the fault; however, a thin veneer of undisturbed soil overlying the fault trace indicates that movement did not occur here during the earthquake.

Dry natural slopes as low as $20^{\circ}$ underlain by semiconsolidated alluvial and colluvial deposits showed minor slumping at two localities along the Little Truckee River north of Russel Valley. Headwall fissures opened as much as 1 inch and the ground surface dropped as much as 3 in. across these fissures; a buried telephone cable was damaged by one of the slumps. A small slide oceurred just above water level on the west side of Prosser Reservoir (fig. 3).

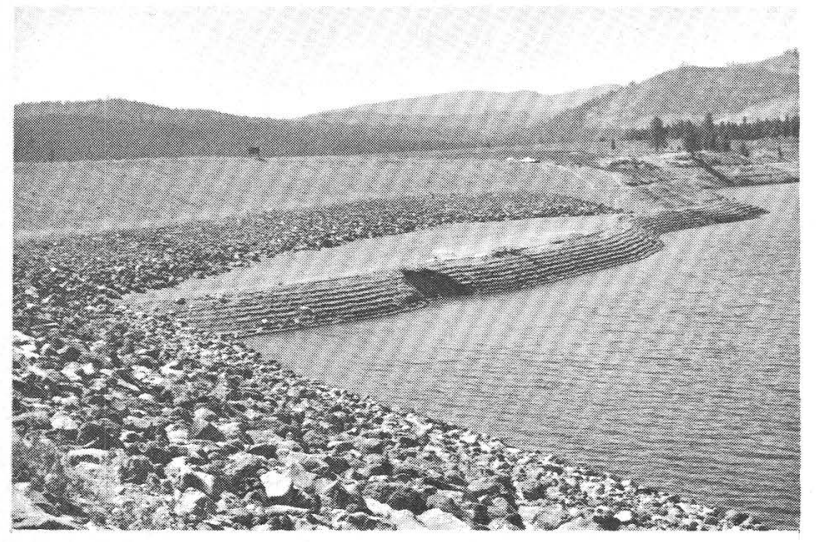

FIGURE 3.- Small slump in unconsolidated alluvial deposits on west bank of Prosser Reservoir; lop of slump about $10 \mathrm{ft}$ above water level; upstream face of Prosser Dam in lower left.

\section{Effects on structures}

DAMS

Three dams were studied-two earthfill and one concrete. Both the Prosser and Boca earthfill dams were damaged, whereas the concrete structure, located at Tahoe City 20 miles south of the epicentral area, sustained slight damage.

Prosser Dam is located about 3 miles southeast of Russel Valley and within a mile of the zone of ground breakage (fig. 2). The dam rests upon lake sediments and apparently received severe seismic shaking. Two axial cracks, one on the downstream side and one on the upstream side of the dam, developed along the northeastward-trending crest and extended over most of its length (figs. 4 and 5). A third less conspicuous crack was confined to the center of the crest. Drill holes by the Bureau of Reclamation indicate that the cracks do not extend into the impervious core of the dam (Brent Crater, oral commun., 1966). Maximum downslope displacement of the well-graded selected compacted fill of 2 in. vertically and 3 in. horizontally occurred in the vicinity of the spillway (fig. 6).

Boca Dam, which also lies 3 miles southeast of Russel Valley, but about 3 miles from the zone of breakage (fig 2) and three-fourths of a mile south of the instrumental epicenter, was less severely damaged than Prosser Dam. Damage to Boca Dam was restricted to small cracks in the earthfill crest of the dam at its junction with the concrete spill. way structure.

The concrete dam on the Truckee River at Tahoe City controls the outflow from Lake Tahoe. This structure is reported to have cracked slightly during the earthquake, but the only cracks noted by the writers during a brief examination of the dam were along construction joints, particularly in the counterfort buttresses, and all appeared to be preearthquake.

\section{BRIDGES}

Most of the damage to highway bridges occurred on Interstate Highway 80 between Donner Lake and Floristan, but one bridge along Highway 89 north of Truckee was damaged slightly. The ensuing discussion on bridge damage is based on information collected by Mr. H. C. Johnson, California Division of Highways, and by R. Kachadoorian and R. F. Yerkes. 


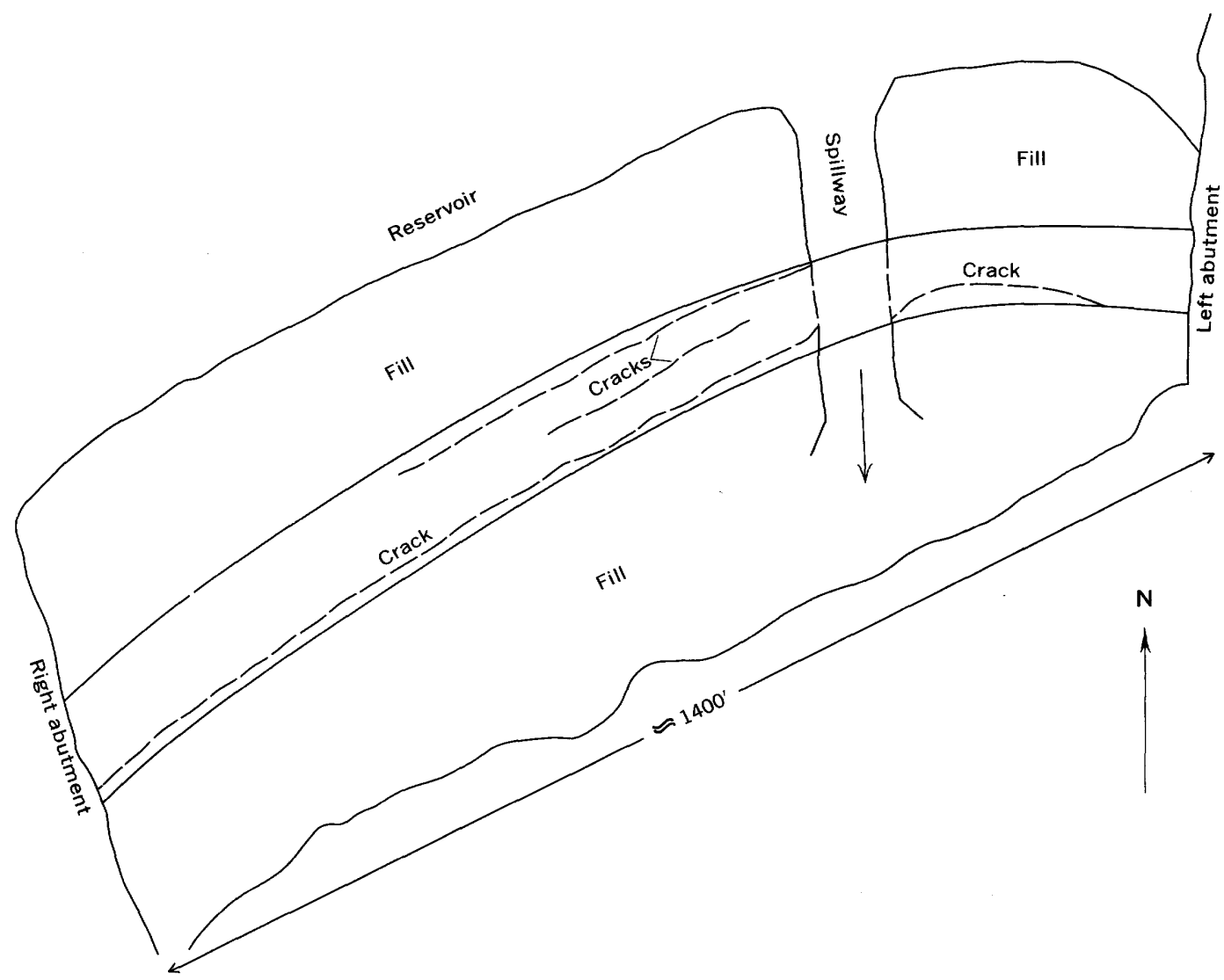

FIGURE 4.-Plan-view of Prosser Dam showing extent and relative locations of cracks in crest of dam.

The two bridges of Interstate Highway 80 at Union Mills, about 5 miles northeast of Truckee, sustained minor but widespread damage (figs. 7 and 8). Damage to the bridge on the eastbound lane included a westward shifting of the east concrete pedestal relative to the abutment and a consequent cracking of the upper part of the abutment during lateral spreading of the abutment fill. Lateral spreading of fill also caused vertical displacement of the approaches. Steel rockers on piers $2,3,4$, and 5 were out of plumb. Slight spalling occurred at the concrete deck expansion joints in response to ramming of the spans against one another during the earthquake. All three concrete pedestals at the west end of the bridge were cracked vertically due to stresses that developed during the earthquake.

Damage to the westbound lane bridge at Union Mills was less severe than that to the eastbound lane bridge. The concrete pedestals of the westbound lane bridge were displaced as much as $11 / 8$ in. relative to the shoe plate by which the stringers are attached to the pedestal, and some lateral displacement downslope of the abutments and pedestals of both approaches occurred (fig. 9).

Minor damage was sustained by the eastbound lane of the Donner Park Exchange bridge on Interstate Highway 80, 11/2 miles west of Truckee. Mr. H. C. Johnson reported that at the south abutment, where the girders rest on steel rockers, the bolts holding the keeper plates were sheared from two of the plates from each of the five bearings (written commun., 1966). The top and bottom keeper plates were sheared off along the easternmost girder, and the rocker moved laterally about 2 in. Johnson also reported a small spall of concrete in the right curb at the south abutment and that the left curb was cracked about $2 \mathrm{ft}$ in from the expansion joint. Damage to this bridge is attributed to lateral displacement of the superstructure relative to the abutments.

At the Donner Lake Interchange bridge of Interstate Highway 80, about 5 miles west of Truckee, artificial fill of the east abutment of the 
westbound lane bridge failed by slumping. This fill consists of decomposed granite that was displaced about $31 / 2 \mathrm{ft}$ southward at the surface; the depth of displacement extended to at least $4 \mathrm{ft}$.

Little or no damage occurred to the bridges from Union Mills east to Floristan. The approaches to the bridges at Floristan and between Union Mills and Boca, however, settled.

The south abutment of the Prosser Creek bridge on Highway 89 just west of Prosser Reservoir was damaged slightly. This damage consisted primarily of spalling of the concrete, probable displacement of the south abutment about half an inch to the west, and cracks in the west curb.

\section{HIGHWAYS}

Artificial fill along a 3-mile section of Interstate Highway 80 southeast of Boca Reservoir locally slumped during the earthquake. The longest of these slumps was a $1,100-\mathrm{ft}$ section near Hinton that failed along the cut-fill contact and resulted in displacements of as much as 6 in. horizontally and 10 in. vertically (figs. 10 and 11). The several smaller failures along the 3 -mile section southeast of Boca Reservoir were chiefly in the eastbound or outer lanes or in filled sections of the highway. The failures occurred at the cut-fill contact.

Additional damage along Interstate Highway 80 was caused by boulders as large as 10 by 10 by 8 tt that fell along cuts especially where the highway passes over or through talus deposits.

\section{RAILROADS}

The Southern Pacific Lines suffered both physical damage and downtime because of the earthquake. Between Boca and the California-Nevada boundary boulders fell onto the rails and halted the westbound traffic. Impact of some of the boulders locally displaced the tracks about $2 \mathrm{in}$. horizontally. Boulders also reportedly fell on a 10 by 12 -ft snowshed and damaged the structure; the exact location of the structure is unknown but was reported by Southern Pacific personnel to be in the Truckee Canyon between Boca and the California-Nevada boundary.

The railway roadbed was displaced both vertically and horizontally where it traverses loose fill over the stream flowing from Boca Reservoir. The tracks here required both realinement and repeated regrading. $\mathrm{Mr}$. Reuben Acala reported that the

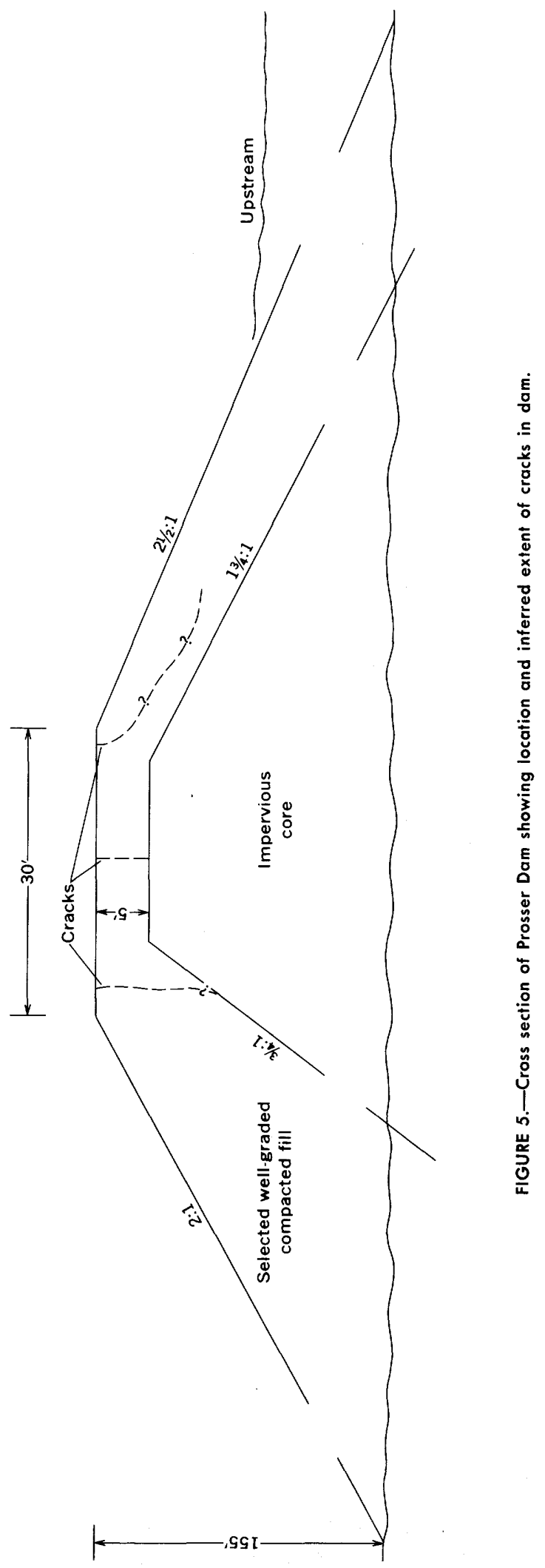




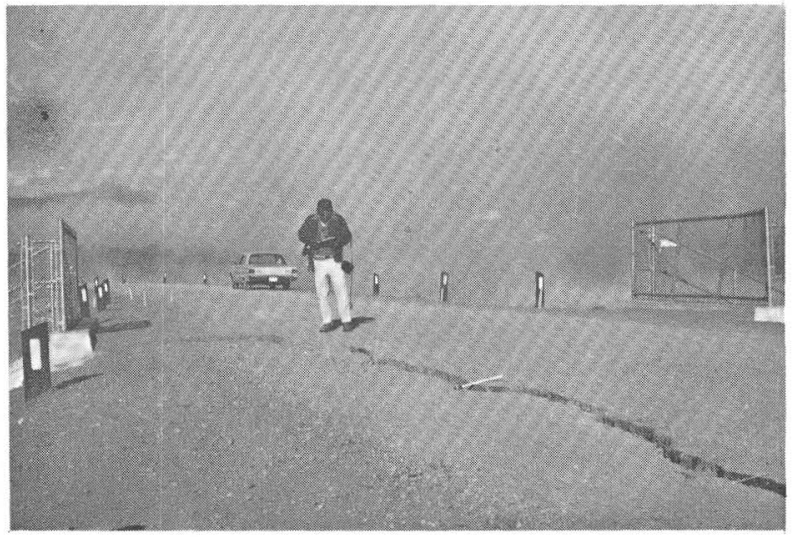

FIGURE 6.- Southwestward view along crest toward right abutment of Prosser Dam. Fence marks spillway near northeast end of dam. Note that crack extends to spillway and stops. Cracks reappear beyond spillway. Left of photograph is downstream. Scale over crack in lower right corner is $63 / 4$ in. long.

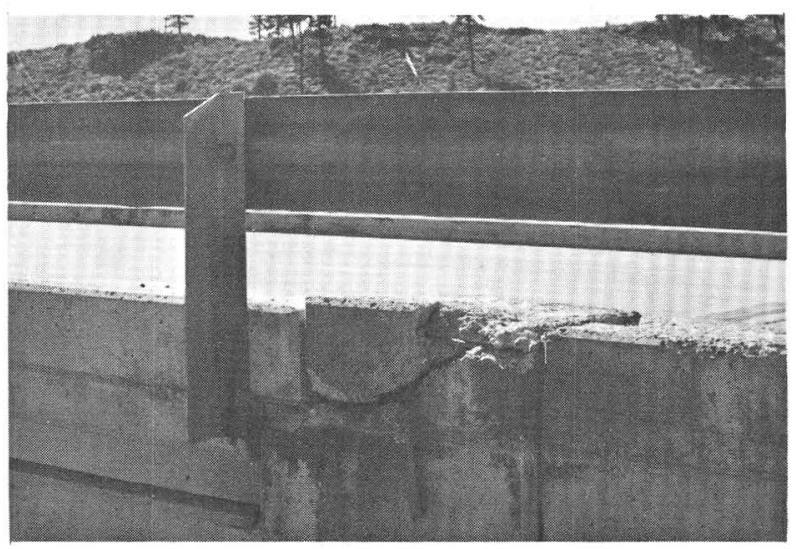

FIGURE 7.-Damage to east abutment of eastbound lane bridge on Interstate Highway 80 where it spans railroad tracks and Truckee River at Union Mills. View to the northeast.

fill was subsiding on September 14, 1966; it was brought to grade three times on September 13 and at least once on September 14.

Small slumps in the railroad grade occurred where the main line passes beneath the Interstate Highway 80 bridge at Union Mills. These slumps extended for about 200 yards but did not include the rails.

\section{BUILDINGS}

Effects on buildings consisted chiefly of toppling or minor damage to chimneys, cracking of plaster, and twisting of rafter beams during swaying. Building damage was confined chiefly to alluviated areas and occurred as far away as Carson City (26 miles southeast of Russel Valley) and Loyalton (18 miles north-northeast). The watermaster's house at Boca Dam, which was built on uncompacted fill consisting of soil and boulders, was severely racked, whereas a nearby garage on cut ground was undamaged. Two chimneys toppled at the roofline, and vibration of the frame stressed the sill anchor bolts, rending and cracking the foundation (fig. 12).

At the Feather River Lumber Co. in Loyalton, a 75 - by 400 -ft shed, made of sheet metal on a wooden frame, oriented with its length trending about N. $45^{\circ}$ W., and built on alluvium, was severely racked and tilted. Damage was so severe that the building was deliberately collapsed.

Large boulders (8-10 ft) fell from cut slopes along Interstate Highway 80 at several localities just west of the California-Nevada boundary. One boulder estimated to weigh 20 tons (Nevada State .Journal, Sept. 13, 1966, p. 7) fell from the west cut of the freeway, skipped eastward across it, continued down the slope toward the Truckee River, and finally punctured the masonry wall of a small powerhouse on the west bank of the river at Farad (fig. 13). Other boulders punctured and crushed the large wooden flumes that service the powerhouse.

\section{OTHER STRUCTURES}

Exposed piplines to the lumber mill at Loyalton were ruptured and separated. Several buried pipelines were ruptured at the watermaster's house at Boca Dam. A power generator at the Drum powerhouse on the Bear River Canal about 4 miles northeast of Auburn (about 60 miles southwest of Russel Valley) was reported to have been out of commission during the earthquake (Nevada State .Journal, Sept. 13, 1966, p. 7). Although communications were not disrupted, there was a break in the sheath of the transcontinental telephone cable near the Little Truckee River.

\section{Miscellaneous effects}

Loose objects (chiefly shelf goods) were selectively displaced in buildings at Loyalton (18 miles northwest of Russel Valley), Verdi (9 miles northeast), Reno (16 miles northeast), the north shore of Lake Tahoe (15 miles south-southeast), Carson City (26 miles southeast), and in the 


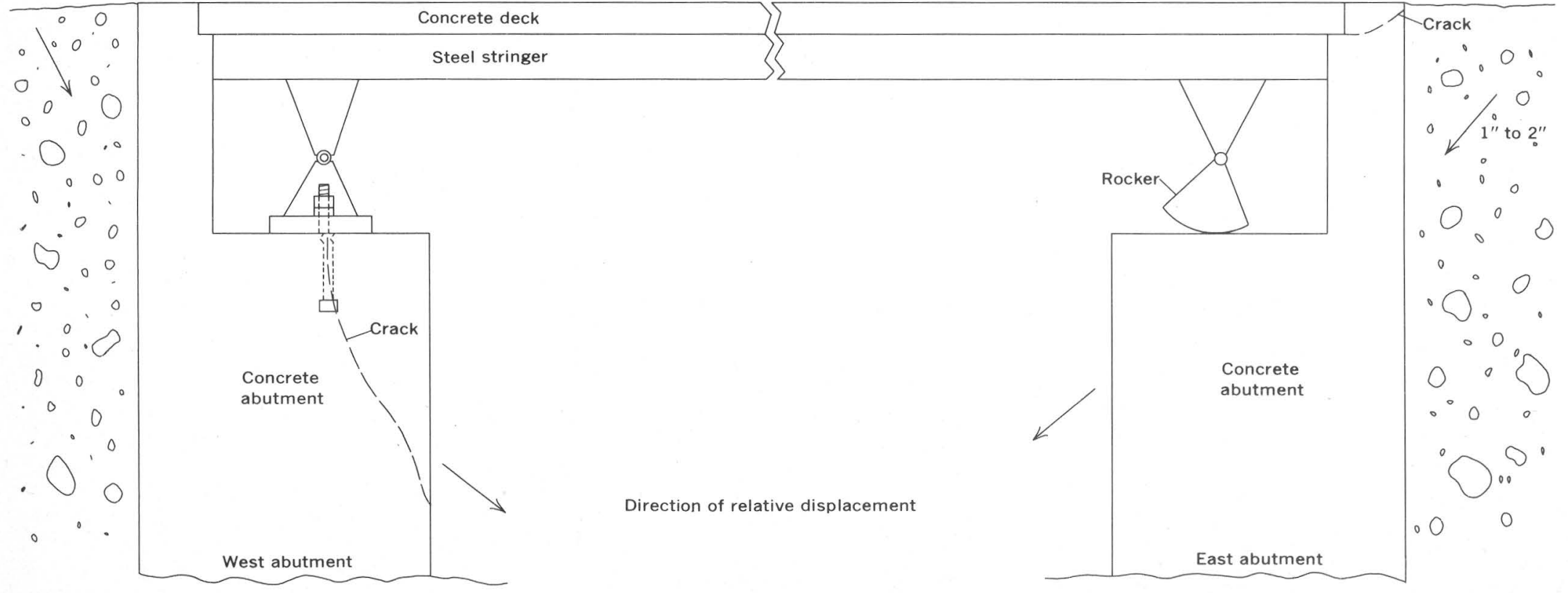

FIGURE 8.-Abutments of eastbound lane bridge of Interstate Highway 80 at Union Mills and type of damage to east and west abutments. 


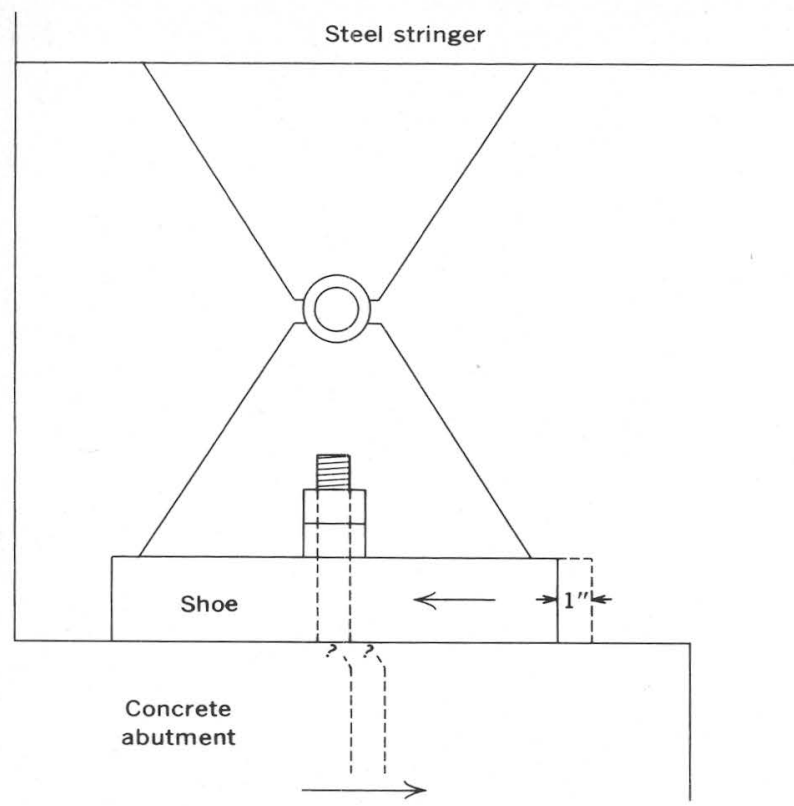

FIGURE 9.-West abutment of westbound lane bridge, Interstate Highway 80 at Union Mills; arrows indicate displacement of pedestal relative to span.

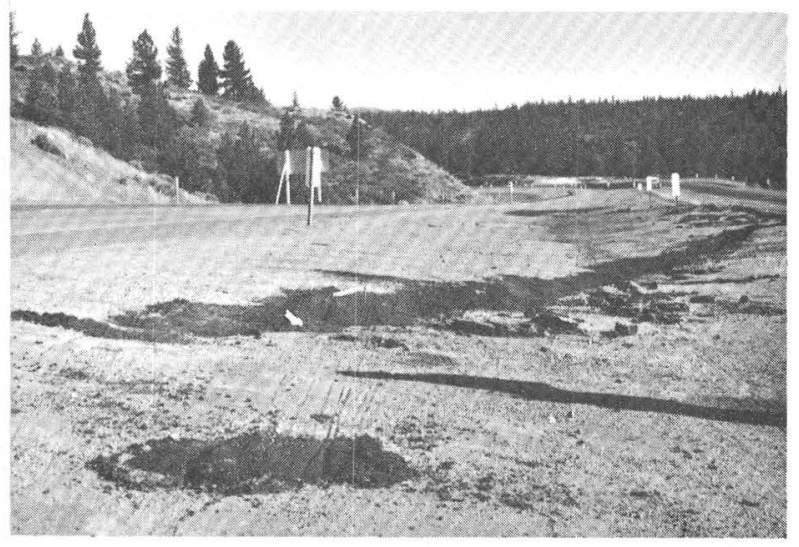

FIGURE 10.-Southward view of repaired crack near Hinton on Interstate Highway 80; leff lanes for westbound traffic and right lanes for eastbound traffic; artificial fill slumped along cut-fill contact and toward open face at right.

Gateway-Truckee area (10 miles south-southwest). In the several instances investigated, a dominant east-west component of swaying was indicated - a direction which agrees with the observed effects of swaying on buildings throughout the area.

\section{EFFECTS ON WATER REGIMEN}

The impact of the earthquake on the water resources of the region consisted principally of water-level fluctuations in response to seismic shock, some increases in the flow of streams near the epicenter, the roiling of water in wells, and small increases in the flow of springs in the Truckee-Russel Valley area in the vicinity of Truckee.

Seismic effects were shown by water-stage recorders at many gaging stations on streams in California and Nevada east of the Sierra Nevada and in the Central Valley of California. The effects, raused largely by wave motion induced in the stilling well of a gage by ground motion associated with the seismic shock, caused movement of the recorder float and consequent vertical tracings on the recorder graph. The rise and fall of the tracings constitute an approximate measure of the severity of the earth shock.

F. C. Craig, a Geological Survey hydrologist, had completed inspection of the water-stage recorder on the Sacramento River at Freeport, 10 miles south of Sacramento, on September 12 just prior to the earthquake. He reported as follows:

I had just finished changing the chart at this station and was still in the gage house when the quake occurred. A crossline had been placed at the beginning of the chart to denote the starting time and, since the movement of the pen was on top of this line, it is impossible to tell with certainty the amount of pen movement that was caused by the quake. This line was placed at 8:40 a.m. P.s.t., but there is usually a little slack in the paper that has to be taken up, so the exact time of the quake was not recorded.

The first effect was a sharp jolt followed immediately by the alarm ery of a pheasant. My first conclusion was that the pheasant had flown into one of the guy cables for the gage, but the shaking continued so an earthquake was evident.

It sounded as though water was sloshing from side to side in the well, and movement of the float wheel became rather rapid and the direction of movement changed abruptly. The movement continued for a minute or so and then subsided.

The instrument is equipped with a pencil as well as a pen. The crossmark made by the pencil is a little blacker and more jagged than a normal crossmark. The black portion suggests that the float movement due to the quake was about a tenth of a foot. This is in line with my observation, although I made no exact readings.

No permanent change or damage was noted at the station. There have been a lot of gas bubbles rising in the water in the vicinity of the gage, but this effect has been noted before.

Shock effects east of the Sierra Nevada were noted at gaging stations over an area extending from Lovelock and Winnemucca, Nev., to Bridgeport, Calif. West of the Sierra Nevada these 


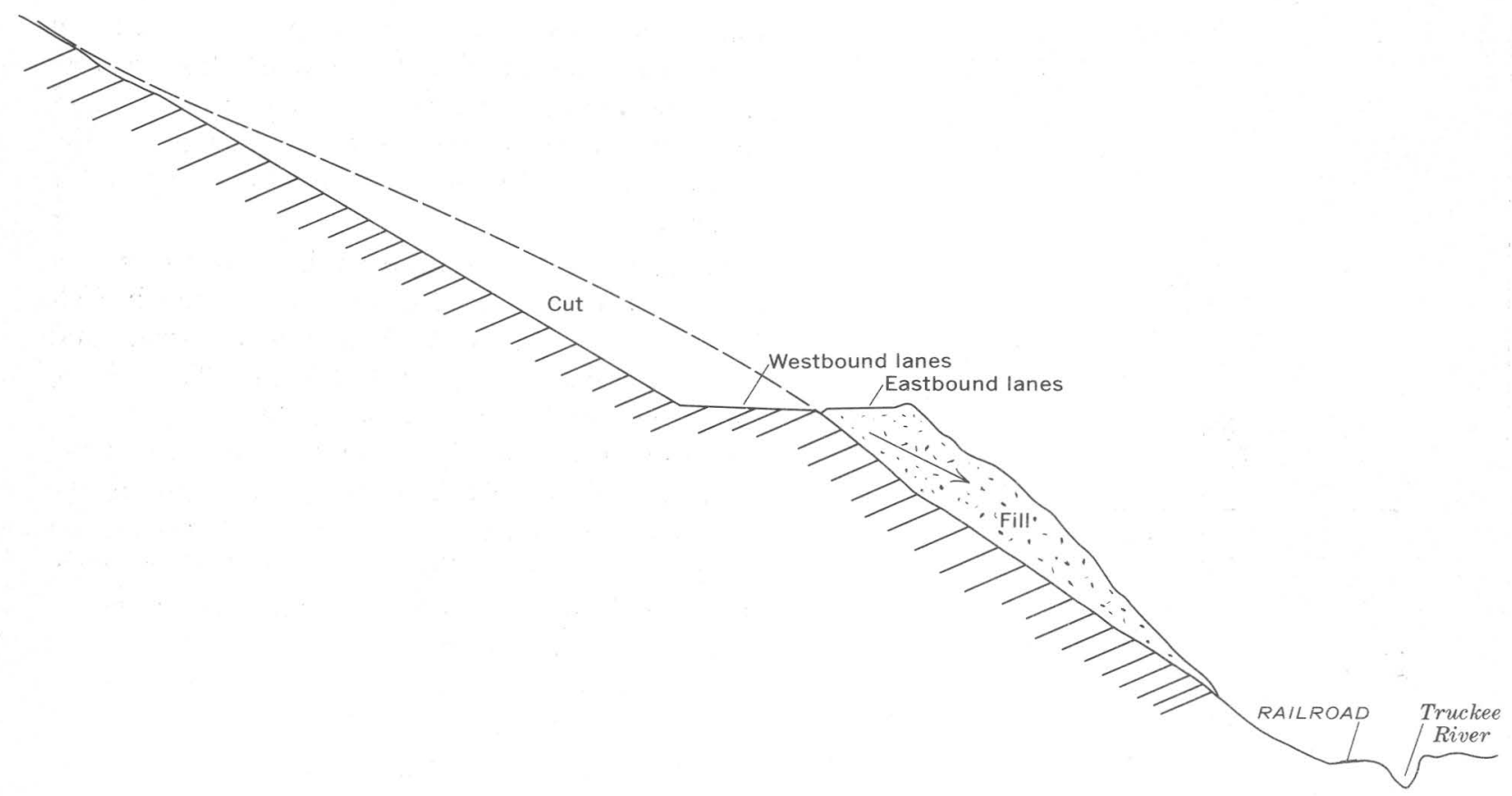

FIGURE 11.-Schematic section of Interstate Highway 80 near Hinton showing location of break at cut-fill contact.

effects were recorded principally in the lower valley areas extending from Red Bluff to Fresno.

Fluctuations recorded at selected gaging stations are listed in table 1; the location of these stations is shown in figure 14. Lesser effects were indicated by the charts from many other stations in the valley and lower foothill areas. Stations in the Sierra Nevada and upper foothill areas on the west slope generally showed little or no effect. For example, the record for Haypress Creek, a headwater tributary of the North Yuba River about 15 miles east

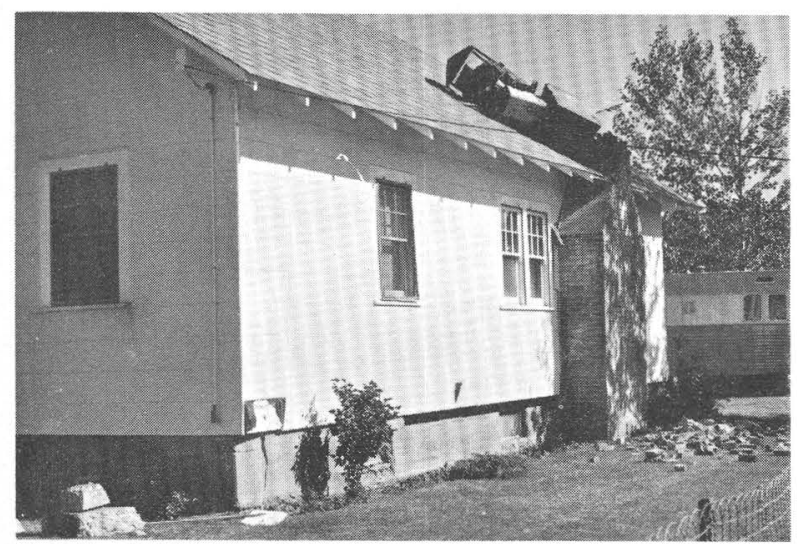

FIGURE 12.-One of two toppled chimneys at watermaster's house, Boca Dam; chimneys on both sides of house toppled eastward. Note cracking and rending of foundations at sill anchor bolts. of Downieville near Sierra City, Calif., and about 20 miles west of the epicenter, showed no noticeable fluctuation. The record for Onion Creek tributary 2, which is 15 miles southwest of the epicenter and within the headwaters of the North Fork American River, however, indicated water-level fluctuations as much as $0.035 \mathrm{ft}$.

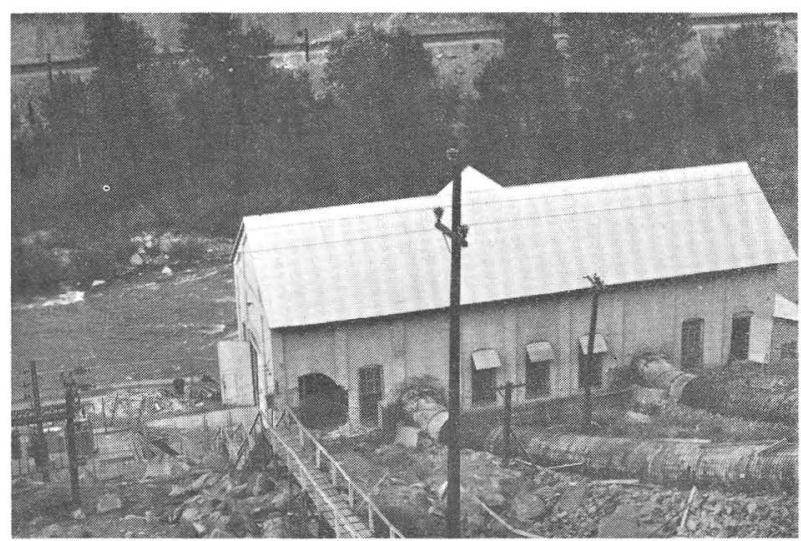

FIGURE 13.-Eastward view of small powerhouse at Farad on Truckee River 3 miles east of Boca Reservoir, showing nearcircular hole about $9 \mathrm{ft}$ in diameter punctured in brick wall (lower left) by large falling boulder. Boulder fell from slope about $100 \mathrm{ft}$ west of Interstate Highway 80 (behind viewer), skipped across the highway and the catwalk (left foreground), and bounced near base of power pole in center and then into the brick wall. 
Table 1.-Fluctuations and net changes in water level recorded at gaging stations, September 12, 1966

\begin{tabular}{c|c|c|c|c}
\hline $\begin{array}{c}\text { No. } \\
\text { on } \\
\text { fig. 14 }\end{array}$ & Station name & $\begin{array}{c}\text { Fluctuations } \\
\text { recorded } \\
\text { as double } \\
\text { amplitude } \\
\text { (feet) }\end{array}$ & $\begin{array}{c}\text { Net } \\
\text { changes } \\
\text { (feet) }\end{array}$ & Remarks \\
\hline
\end{tabular}

TRUCKEE RIVER BASIN

\begin{tabular}{|c|c|c|c|c|}
\hline $1 \ldots$ & Lake Tahoe at Tahoe City..... & 0.40 & 0.00 & Swell of $3 \frac{1}{2} \mathrm{ft}$ reported. \\
\hline 2 & Prosser Creek near Boca.... & .15 & +.03 & $\begin{array}{l}\text { Flow increased from } 338 \text { to } 355 \\
\text { cfs in } 20 \mathrm{~min} \text {, then declined } \\
\text { to } 345 \mathrm{cfs} \text { in } 30 \mathrm{~min} .\end{array}$ \\
\hline 3 & $\begin{array}{l}\text { Little Truckee River above } \\
\text { Boca Reservoir, near Boca. }\end{array}$ & .11 & +.03 & $\begin{array}{l}\text { Flow increased from } 10 \text { to } 11 \\
\text { cfs in } 3 \mathrm{hr} \text {, then declined } \\
\text { slightly. }\end{array}$ \\
\hline
\end{tabular}

SACRAMENTO RIVER BASIN

\begin{tabular}{|c|c|c|c|c|}
\hline 4. & $\begin{array}{l}\text { Sacramento River near Red } \\
\text { Bluff. }\end{array}$ & 0.03 & 0.00 & \\
\hline 5. & $\begin{array}{l}\text { Stony Creek below Black Butte } \\
\text { Dam, near Orland. }\end{array}$ & .04 & .00 & \\
\hline 6 . & $\begin{array}{l}\text { Sacramento River at Butte } \\
\text { City. }\end{array}$ & .03 & .00 & \\
\hline & $\begin{array}{l}\text { Haypress Creek near Sierra } \\
\text { City. }\end{array}$ & .00 & .00 & $\begin{array}{l}\text { Station about } 20 \text { miles west of } \\
\text { epicenter. }\end{array}$ \\
\hline & $\begin{array}{l}\text { Onion Creek tributary } 2 \text { near } \\
\text { Soda Springs. }\end{array}$ & .035 & .00 & \\
\hline 9 & Feather River at Nicolaus .... & .07 & .00 & \\
\hline $10 \ldots$ & Yolo bypass near Woodland ...- & .035 & .00 & \\
\hline $11 \ldots$ & American River at Fair Oaks_. & .02 & .00 & \\
\hline 12 - & Sacramento River at Freeport_ & .10 & .00 & Approximate. \\
\hline
\end{tabular}

Parts of recorder charts showing fluctuations in response to the principal seismic shock on September 12, 1966, at four selected gaging stations are reproduced in figure 15 . The record for Feather River at Nicolaus, Calif., shows a direct response to the seismic shock and is representative of the records at most gaging stations.

Change in streamflow-a significant and common response of the water regimen to earthquakes - is indicated by the records for Little Truckee River and Prosser Creek. Flow in Little Truckee River above Boca Reservoir increased from a unitorm 10 efs (cubic ft per sec) before the earthquake to 11 efs 3 hours after the principal shock, possibly in response to increased outflow from springs. Flow in Prosser Creek, which is regulated by Prosser Dam 11/4 miles upstream, increased from 338 to 355 efs in a 20 -minute period, then declined to a stable 345 efs in the following 30 minutes. The initial change in discharge may be attributable to release of water from bank storage in the reach of the stream channel below the dam as a result of the shock. The apparent continuing increase in postearthquake flow, however, may result from factors such as increase in discharge of springs below the dam or small changes in gate openings at the dam following the shaking; alternatively, it may indicate a change in the stage-discharge relation. The datum of the gage had been checked shortly before the quake, and a recheck on September 16 indicated that no change had occurred.

A secondhand report of waves on Lake Tahoe during the earthquake was not verified. A man in a small boat near the south shore reported that water appeared to boil up from the bottom of the 


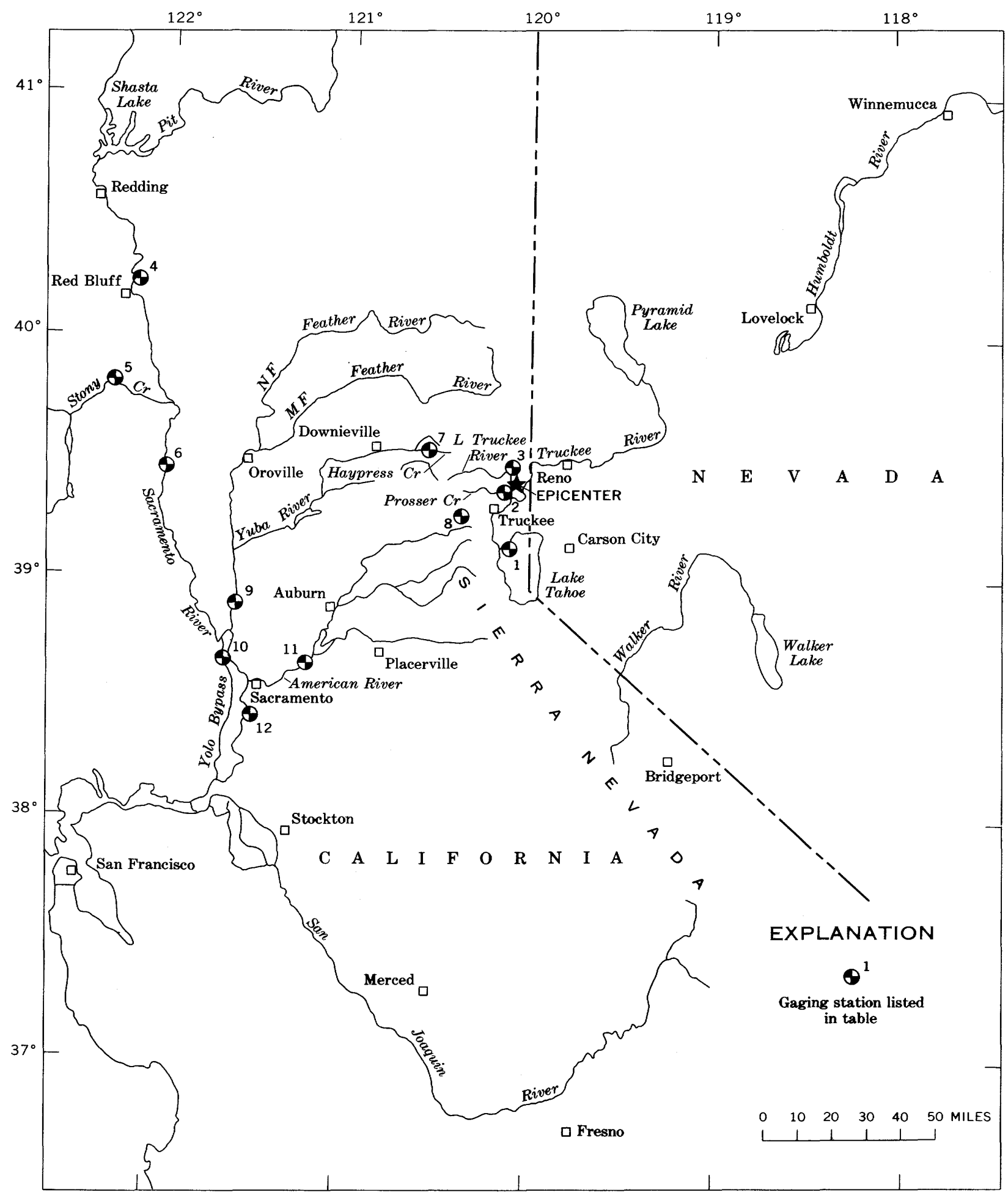

FIGURE 14.- Selected gaging stations whose records showed effects of the Truckee earthquake, September 12, 1966. Gaging stations listed in table 1. 


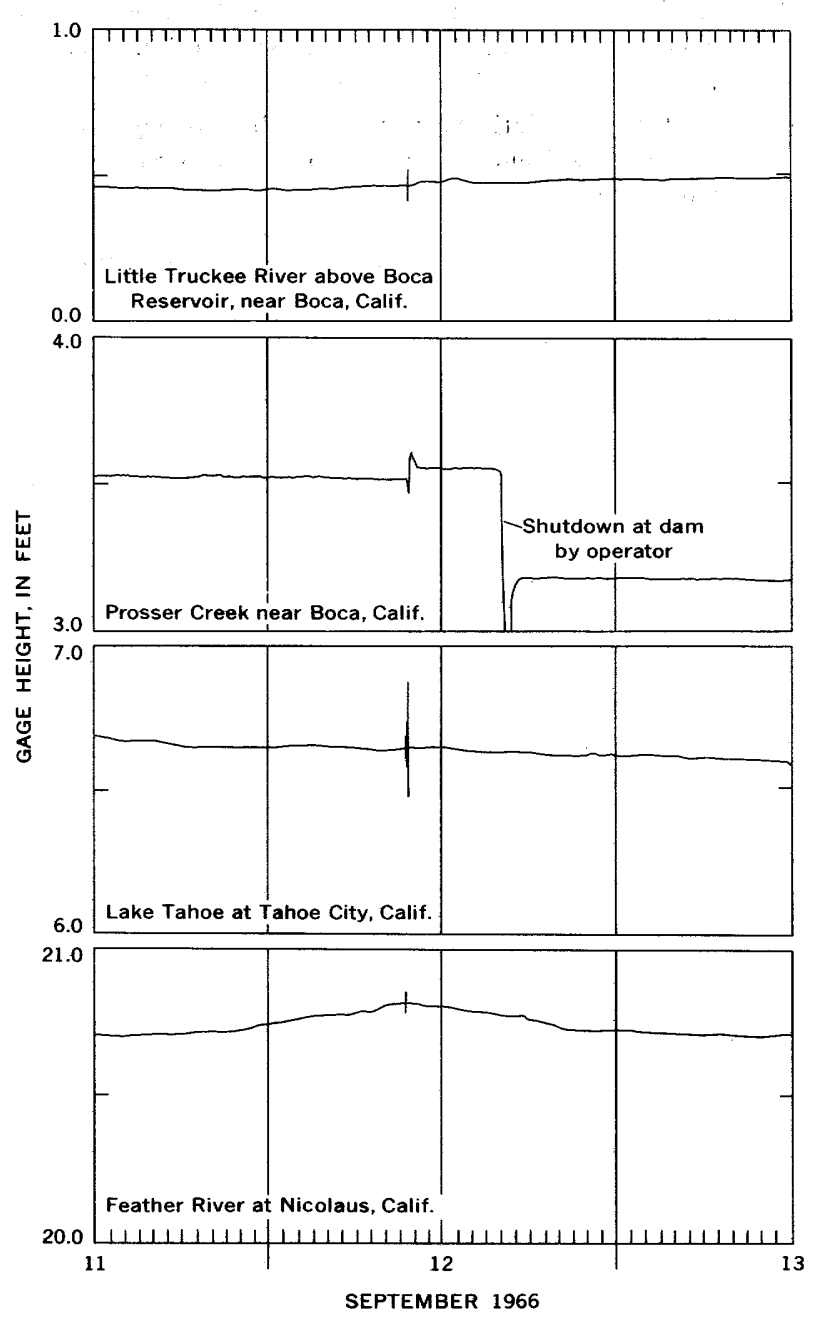

FIGURE 15.-Fluctuations recorded at gaging stations in response to the Truckee earthquake.

lake and that the ensuing violent waves caused him to make for shore. This report might describe the result of a subaqueous landslide in that part of the lake. However, the watch on duty September 12,1966 , at the north-shore station of the U.S. Coast and Geodetic Survey reported that before the earthquake a strong south wind had caused whitecaps on the northern part of the lake and that a $31 / 2$-ft swell was running. The same witness remarked that no unusual effects occurred on the lake during the earthquake. The swell was not unusually high for the climatic conditions, and it would probably have masked small seiches (periodic water-level oscillations).

The record for Lake Tahoe at Tahoe City (fig. 15), obtained at a pier $1,000 \mathrm{ft}$ east of the dam at the outlet near the north end of the lake, indicates a surge in the gage well of $0.40 \mathrm{ft}$. The stilling well for this gage is 24 in. in diameter and is equipped with a $1 / 4$-in.-diameter inlet to damp local wave action. The stage in the well thus does not respond fully to rapid stage changes in the lake, and the complete range of transitory waves, such as swells and seiches, may not be recorded.

Ungaged water-supply wells, springs, and distribution systems in the Truckee-Russel Valley area north of Truckee also were affected by the earthquake.

The town of Truckee obtains its water supply from springs and wells at three localities. The water from these sources was muddied following the quake and did not completely clear up until September 16 or 4 days after the quake. In addition, a 6-in. main supply line was broken at Truckee. Mr. Francis Longo, manager of the Truckee Utility District, reported that there was a similar occurrence after an earthquake in the autumn of 1961.

Springs in Hoke Valley, $4 \frac{1}{2}$ miles northeast of Russel Valley, and in Sardine Valley, 3 miles north of Russel Valley, showed increases in flow, and the water was murky after the earthquake. On September 15 the flow in these springs had not returned to the preearthquake levels, although the water in most had cleared up.

Dr. Louis J. Payen, a rancher in Sardine Valley stated that before the earthquake he could drive anywhere in the valley without difficulty, whereas after the earthquake such travel was difficult because of the damp ground. Local accumulations of standing water were noted at the north end of the valley on September 14, 1966.

A water well being drilled in a development south of Prosser Reservoir and about 3 miles north of Truckee was dry and open to a depth of $570 \mathrm{ft}$ on September 11; when it was reentered on September 13 , the hole was obstructed at $300 \mathrm{ft}$ and was wet. The well is on or near the southwesterly continuation of the ground breakage which trends N. $30^{\circ}$ E.

\section{REFERENCES CITED}

Birkeland, P. A., 1963, Pleistocene volcanism and deformation of the Truckee area, north of Lake Tahoe, California: Geol. Soc. America Bull., v. 74, no. 12, p. 1453-1464.

Burnett, J. L., and Jennings, C. W., 1962, Geologic map of 
California, Olaf P. Jenkins edition, Chico sheet: California Div. Mines and Geology, scale $1: 250,000$.

California Department Water Resources, 1964, Faults and earthquake epicenters in California, in Crustal strain and fault movement investigation: California Dept. Water Resources Bull. 116-2, 96 p.
Coulter, H. W., and Migliaccio, R. R., 1966, Effects of the earthquake of March 27, 1964 at Valdez, Alaska: U.S. Geol. Survey Prof. Paper 542-C, p. C1-C36.

U.S. Coast and Geodetic Survey, 1966, Preliminary determinations of epicenters: U.S. Coast and Geod. Survey Card 67-66. 
